\title{
STRONG TEST PRESSURE CONCRETE USE OF ASBEST WASTE
}

\author{
Saiful Muslimin ${ }^{1}$, Suwarno $^{2}$, April Gunarto ${ }^{3}$, M. Zaenuri $^{4}$ \\ Kadiri University \\ saiful_muslimin@unik-kediri.ac.id
}

\begin{abstract}
Concrete is a significant and most dominant material used in building structures. Concrete consists of a mixture of cement, aggregate, water, and added ingredients. Concrete said material has an essential role in making concrete because it can change the real properties to suit the needs. $\mathrm{Li}$, asbestos is a concrete-added material that can reduce the use of cement and produce concrete with absolute consistency. The purpose of this study was to determine how the effect of adding asbestos waste to cement. The method used is an experimental method based on previous research. The specimen used was cylindrical with a diameter of $15 \mathrm{~cm}$ and a height of $30 \mathrm{~cm}$. The percentage variation of asbestos waste addition is $0 \%, 50 \%$, and $100 \%$ of the weight of cement used. Typical concrete test results obtained an average value of $22.08 \mathrm{MPa}$, a $50 \%$ percentage produces an average compressive strength of $21.32 \mathrm{MPa}$, and a portion of $100 \%$ provides a compressive strength of $22.93 \mathrm{MPa}$. Then the results of the then actual strength test have increased in the percentage of asbestos waste $100 \%$.
\end{abstract}

Keywords: Compressive Strength Test, Admixture Concrete, Asbestos Waste

\section{INTRODUCTION}

Concrete is an essential and most dominant material used in building structures with the main component being cement.(Zhang \& Zhang, 2019) Concrete is also a construction that has many advantages including, strong resistance to compressive forces, resistance to weather changes, more resistance to high temperature, easily formed according to need, and easy to work. And concrete is an artificial stone that has a high enough compressive strength, made from a mixture of cement, sand, broken gravel, and water. Current development developments cause the need for building materials to increase.(Maghfouri et al., 2017) Growth in the field of structure is currently experiencing very rapid progress, taking place in various areas.(Ratnawulan et al., 2018) This is because there are many advantages of concrete compared to other materials, that is, the price is relatively low, has good strength, the constituent raw materials are natural to obtain, durable, resistant to fire.(S Winarto, 2020)

Almost every aspect of human life is always associated with concrete, both directly and indirectly. For example are roads and bridges whose structures are made of concrete, airfields, breakwaters, dams.(Chai Lee et al., 2019) Now that there has been an increase in global temperatures globally, it is necessary to innovate in Civil Engineering by utilizing unused asbestos waste in concrete mixtures.(Candra, 2020) As the demand for concrete increases, it is required to have a mix of concrete that is environmentally friendly and has economic value so that it can contribute to reducing increasing global warming.(Gowdham et al., 2017) This study aims to determine how the influence of asbestos waste on the compressive strength to reduce cement.(Cahyo, 2020)

\section{LITERATURE REVIEW}

Concrete is a building material obtained from the mixture of cement, water, fine aggregate, coarse aggregate with a specific ratio, and sometimes added to the mixture. According to Chu-Kia 
Wang \& Charles G. Salmon (Design Reinforced Concrete: 1985), Plain Concrete is based on mixing cement, fine aggregate, coarse aggregate, water and sometimes other mixtures.

\section{Concrete Classification}

Classification of concrete according to class is divided into 3, namely:

A. Class I concrete is concrete for non-structural works. For implementation, there is no need for specialized expertise. Quality control is only limited to light supervision of the quality of the ingredients, whereas compressive strength is not required for inspection. Class I quality is expressed as Bo.(Ridwan et al., n.d.)

B. Class II concrete is concrete for general structural works. Implementation requires sufficient expertise and must be carried out under the leadership of experts. Concrete class II is divided into standard qualities $\mathrm{B} 1, \mathrm{~K} 125, \mathrm{~K} 175$, and $\mathrm{K} 225$. In the B1 quality, quality control is only limited to the supervision of the quality of the ingredients.(Larsen et al., 2017) At the same time, the compressive strength is not required for inspection, on the quality of K125, K175, with the necessity to check the concrete compressive strength continuously from the results of the test specimens.(Badan Standardisasi Nasional, 2002)

C. Class III concrete is concrete for structural works higher than K225. Implementation requires special expertise and must be carried out under the leadership of experts. Required a concrete laboratory with complete equipment that is served by experts who can carry out continuous quality control of concrete.(Kusumawardaningsih et al., 2015)

\section{Concrete Composite Material}

Concrete constituent materials significantly affect the compressive strength of concrete specific constituent materials themselves include cement, aggregate, water, and without added ingredients where each added material has a different function.(Larsen et al., 2017)

A. Cement

Cement (Portland Cement) is a hydraulic building material that is adhesive, hardens when reacting with water, resistant and stable in water obtained from the blending of the clinker grains (clinker) with the addition of gypsum.(Badan Standardisasi Nasional, 2002) This cement is a material in the form of powder or fine granules with sizes ranging from (45-75) $\mu \mathrm{m}$, greengray, and thermodynamically unstable, which tends to react with water to form stable hydration products. This cement is a factory product made from natural raw materials that require high technology and a considerable cost to process it

B. Water

According to Tjokrodimuljo (1996), water is used for mixing cement, as well as being a lubricant between aggregate grains so that it is easy to work and compact. To react with cement, the water needed is only about $25 \%$ by weight of the cement, but in reality, the value of the cement water factor used is difficult to be less than 0.35 . This excess water used as a lubricant. Additional water for this lubricant should not be too much because the strength of the concrete will below, and the concrete porous.(Chan \& Chu, 2004) Water that meets the requirements as drinking water also meets the requirements for concrete mix materials.(Candra, 2020) In general, water that can use for concrete admixtures is water, which, if used, can produce concrete with a strength of more than $90 \%$ strength of concrete that uses distilled water.

\section{Aggregate}

Aggregates are mineral grains that are the result of the natural disintegration of stones or also called in the form of stone breaking with natural stones. aggregates are concrete fillers, but the 
role of aggregates in concrete is significant.(Pujianto, 2011) The total concrete content is around $70 \%-75 \%$ of the concrete volume. Aggregates have a lot of influence on the properties of concrete, so the aggregate selection is an essential part of making concrete. (Qasim, 2018) In general, the aggregates used contain inert compounds, wherein inactive compounds are compounds that do not react chemically.(Qasim, 2018)

\section{Fine Aggregate}

Sand is one type of aggregate which needed for concrete-making materials ranging in size from 0.0625 to $2 \mathrm{~mm}$. formation of sand due to physical and chemical weathering processes in rocks. According to PBI 1971 (NI-2) article 33, the conditions for fine aggregate (sand) are as follows:

a. "Fine aggregates consist of sharp and hard grains, which are eternal in the sense that they are not broken or destroyed by the effects of the weather, such as the sun's heat and rain.(Dachlan \& Setiadji, 2015)

b. Fine aggregate must not contain sludge more than $5 \%$ of the total weight of dry aggregate. If the mud content is more than $5 \%$, the fine aggregate must wash first.

c. Fine aggregates should not contain too much organic matter. can be proven with the Abrams Harder color experiment by using $\mathrm{NaOH}$ solution.(Sathyan et al., 2018)

d. Fine aggregates consist of granules of varying magnitude and if sifted by the sieve arrangement specified in article 3.5 paragraph 1 (PBI 1971), must meet the following conditions:

a. Remaining above $4 \mathrm{~mm}$ sieve must be at least $2 \%$ by weight.

b. Remaining above $1 \mathrm{~mm}$ sieve must be at least $10 \%$ by weight.

c. Remaining above a $0.25 \mathrm{~mm}$ sieve should range between $80 \%-90 \%$ by weight ".

The function of fine aggregates is to provide stability and reduce the permanent deformation of pavement through interlocking and friction between the grains (Sarah et al., 2019). For this reason, the external properties required are angularity and roughness. particle surface roughness.

\section{Rough Aggregate}

Coarse aggregate is commonly called gravel because of the disintegration of natural stones or in the form of broken stones obtained from natural stones, with grains between $4.76 \mathrm{~mm}-150$ $\mathrm{mm}$.(Badan Standardisasi Nasional, 2002) 1 Provisions of coarse aggregate include:

a. Coarse aggregate must consist of hard and non-porous granules. Coarse aggregate with flat pellets can only in use if the number of flat grains does not exceed $20 \%$ of the total weight of the sum.

b. Coarse aggregate must not contain sludge of more than $1 \%$ in its dry weight. If it exceeds, it must wash

c. Coarse aggregate must not contain substances that can damage concrete, such as substances that are relatively alkaline.

d. Coarse aggregate for concrete can be natural gravel from broken stone.

e. The rough aggregate must pass a hardness test with a Rudeloff test vessel with a test load of 20 tons.

f. Levels of weak parts if tested with a maximum of $5 \%$ copper rod scratches. 
g. Fineness Modulus for Coarse Aggregate between 6-7.5

Common types of rough aggregates are:

1. Naturally broken stone: This material obtained from rock or typically crushed stone excavated.

2. Natural gravel: Gravel is obtained from natural processes, namely from the river bank or riverbed erosion.

3. Artificial coarse aggregate: Mainly in the form of slag or shale, used to light-weighted concrete.

4. Aggregates for nuclear armor and heavy weight: Coarse aggregates classified here for example broken steel, barite, magnatite and limonite

3. Asbestos waste

Asbestos (Asbestos) is a mineral in the form of fine fibers that occur naturally. According to the definition given by Occupational Safety and Health Administration (OSHA), there are six types of minerals categorized as asbestos materials as follows: Chrysotile, Riobeckite, Grunarite, Actinolite, Anthophyllite, and Thermolite. from chemistry, asbestos is a substance consisting of magnesium, calcium, and fibrous building fibers with powerful physical properties. Asbestos waste classified as B3 waste, which is harmful to human health and the environment. However, it is used as a substitute for cement in concrete production. Asbestos waste is not hazardous to human health because it is mixed with other materials such as water, glue, and sand.

\section{Concrete Slump Test}

Slump is the amount of vertical collapse value caused by concrete not having sufficient yield stress limit to hold its weight because the bond between the particles is still weak, so it is unable to maintain its original relationship.(Chai Lee et al., 2019)The slump test is an empirical analysis / the method used to determine the consistency/stiffness (workable or not) of a fresh concrete mixture to assess its workability level.(Malier, 1992)

\section{Making Test Objects}

The making of this test object aims to facilitate the process of testing concrete in certain shapes such as cylinders. The cylinder specimens used in this study were $150 \mathrm{~mm}$ in diameter and $300 \mathrm{~mm}$ high.

\section{Concrete Care}

Concrete care is needed from the start,

namely the period of development of his strength. There are three conditions required to get proper care, namely:

a. The continual availability of moisture.

b. Supporting temperature $\left(23^{\circ} \mathrm{C}-28^{\circ} \mathrm{C}\right)$.

c. Time (the longer, the better).

In this study, treatment was carried out by soaking the dried concrete into a pool filled with water for seven days, 14 days, and 28 days of treatment.

\section{Compressive Strength Test}

The strength of concrete is considered the most crucial characteristic in some cases. Concrete is more durable in resisting compressive stress than other stresses and generally benefits from this property when planning concrete structures.(Kasim et al., 2019) Concrete compressive strength is a measure of the area of the unit load that causes the concrete test object to break when loaded with a 
specific compressive force produced by a press machine testing the compressive strength of concrete using a press machine. The test specimen is placed in the machine pressure plane centrally, done slowly until the concrete is crushed.(Breu et al., 2008)

$$
f c^{\prime}=\frac{\mathbf{P}}{\mathbf{A}}
$$

With information:

$\mathrm{fc}$ '= Concrete compressive strength (Mpa)

$\mathrm{P}=$ maximum load weight $(\mathrm{N})$

$A=$ Test surface area $\left(\mathrm{mm}^{2}\right) \mathrm{P}=$ maximum load weight $(\mathrm{N})$

$A=$ Test surface area $\left(\mathrm{mm}^{2}\right)$

\section{METHODOLOGY}

This research was conducted at the Civil Engineering Laboratory of Kediri University, with the method used was experimental and studied previous research theories. The analysis was carried out by making standard concrete and modified concrete with the addition of asbestos waste admixture. This research began with the preparation of tools and materials and then tested the materials to be used to make concrete. After checking the materials and the results meet the requirements, a mixture of planning and making of concrete test specimens (curing) of the test specimens. Care (curing) of concrete at average temperatures $20^{\circ}-30^{\circ} \mathrm{C}$ is carried out by inserting concrete into clean water with a temperature of $20^{\circ}-30^{\circ} \mathrm{C}$ for 28 days, then tested the compressive strength of concrete using a press machine.

\section{Testing Procedure}

This test includes material preparation, material testing, mix design, then new concrete production, slump testing, making of test objects, concrete treatment, and concrete compressive strength testing (Angjaya et al., 2013). Concrete compressive strength testing is intended to find a strength comparison. press the plan of $\mathrm{fc}^{\prime}=20 \mathrm{MPa}$ with the resulting compressive strength, becoming the benchmark in the field. Then, the values are analyzed. The age variation of treatments used is 14 days and 28 days. The percentage of the mixture used is $0 \%, 50 \%, 100 \%$.

\section{RESULTS}

\section{Material Test Results}

Materials and materials used in this study include Portland cement, water, broken stones, sand, and asbestos waste. Before being used to make test objects, the above materials on the test for their characteristics. This examination was carried out at the Kadiri University Civil Engineering Laboratory.

Table 1. results of fine aggregate testing

\begin{tabular}{|c|l|c|c|c|}
\hline NO & CHARACTERISTICS & SPECIFICATION & $\begin{array}{c}\text { TEST } \\
\text { RESULTS }\end{array}$ & INFORMATION \\
\hline 1 & Water content & $2 \%-5 \%$ & $1,01 \%$ & Fulfill \\
\hline 2 & Sludge levels & Maks $5 \%$ & $1,00 \%$ & Fulfill \\
\hline 3 & Volume Weight & & & Fulfill \\
\hline & a. Free & $1,6-1,9 \mathrm{~kg} /$ liter & 1,61 & Fulfill \\
\cline { 2 - 5 } & b. Solid & $1,6-1,9 \mathrm{~kg} /$ liter & 1,63 & Fulfill \\
\hline
\end{tabular}


THE SPIRIT OF SOCIETY JOURNAL

International Joumal of Society Development and Engagement

ISSN : 2597-4777 (Online) - ISSN : 2597-4742 (Print)

This work is licensed under a Creative Commons Attrib ution-ShareAlike 4.0 International License.

\begin{tabular}{|l|l|c|c|c|}
\cline { 2 - 5 } 4 & Absorption & Maks $2 \%$ & $1,01 \%$ & Fulfill \\
\hline 5 & Specific gravity & & & Fulfill \\
\hline \multirow{3}{*}{} & a Bj. Bulk & $1,6-3,3$ & 2,64 & Fulfill \\
\cline { 2 - 5 } & b Bj. Dry Surface & $1,6-3,3$ & 2,67 & Fulfill \\
\cline { 2 - 5 } & c. Bj. Pseudo & $1,6-3,3$ & 2,71 & Fulfill \\
\hline \multirow{2}{*}{6} & $\begin{array}{l}\text { Modulus of } \\
\text { Refinement }\end{array}$ & $1,5-3,8$ & 2,45 & Fulfill \\
\hline
\end{tabular}

Source : fine aggregate test results

Table 1. shows that the results of the excellent aggregate test have met the predetermined requirements

Table 2. coarse aggregate test results

\begin{tabular}{|c|l|c|c|c|}
\hline NO & CHARACTERISTICS & SPECIFICATION & $\begin{array}{c}\text { TEST } \\
\text { RESULTS }\end{array}$ & INFORMATION \\
\hline 1 & Water content & $0,5 \%-2 \%$ & $1,01 \%$ & Fulfill \\
\hline 2 & Sludge levels & $0,2 \%-1 \%$ & $1,00 \%$ & Fulfill \\
\hline 3 & Volume Weight & & & Fulfill \\
\hline \multirow{2}{*}{} & a. Free & $1,6-1,9 \mathrm{~kg} /$ liter & 1,68 & Fulfill \\
\cline { 2 - 5 } & b. Solid & $1,6-1,9 \mathrm{~kg} /$ liter & 1,78 & Fulfill \\
\hline 4 & Absorption & Maks $4 \%$ & $1,01 \%$ & Fulfill \\
\hline 5 & Specific gravity & & & Fulfill \\
\hline \multirow{2}{*}{} & a Bj. Bulk & $1,6-3,3$ & 2,15 & Fulfill \\
\cline { 2 - 5 } & b Bj. Dry Surface & $1,6-3,3$ & 3,24 & Fulfill \\
\cline { 2 - 5 } & c. Bj. Pseudo & $1,6-3,3$ & 2,2 & Fulfill \\
\hline \multirow{2}{*}{6} & $\begin{array}{l}\text { Modulus of } \\
\text { Refinement }\end{array}$ & $6,0-7,1$ & 6 & Fulfill \\
\hline
\end{tabular}

Source : coarse aggregate test results

Table 2. shows that the coarse aggregate test results have met the predetermined requirements

\section{Job mix Concrete}

The preparation of the composition of the mixture used in the manufacture of specimens refers to SNI 7394: 2008 concerning concrete mixtures every $1 \mathrm{~m}^{3}$ (ASTM C33-16, 2016) The targeted real quality is $\mathrm{K}-225$ or the equivalent of $\mathrm{fc}$ ' $18.675 \mathrm{MPa}$. The percentage of asbestos waste used was $0 \%, 50 \%$, and $100 \%$ with five specimens for each variable. The composition of the ingredients is presented in the following table

Table 3. Jobmix Concrete Modification Per 1m3

\begin{tabular}{|c|c|c|c|c|c|}
\hline \multirow{2}{*}{$\begin{array}{c}\text { TEST OBJECT } \\
\text { CODE }\end{array}$} & CEMENT & SAND & CORAL & WATER & ADDITION \\
\cline { 2 - 6 } & $K g$ & $K g$ & $K g$ & $L$ & $K g$ \\
\hline BT-N & 348 & 692 & 1039 & 215 & - \\
\hline BT-N-L Asbes 50\% & 172 & 692 & 1039 & 215 & 174 \\
\hline BT-L Asbes 100\% & - & 692 & 1039 & 215 & 348 \\
\hline
\end{tabular}


THE SPIRIT OF SOCIETY JOURNAL

International Joumal of Society Development and Engagement

ISSN : 2597-4777 (Online) - ISSN : 2597-4742 (Print)

This work is licensed under a Creative Commons Attrib ution-ShareAlike 4.0 International License.

Source : plan Jobmix Concrete Modification Per $1 m 3$

Table 4. Jobmix Concrete Modified Per Cylinder

\begin{tabular}{|c|c|c|c|c|c|}
\hline \multirow{2}{*}{$\begin{array}{c}\text { TEST OBJECT } \\
\text { CODE }\end{array}$} & CEMENT & SAND & CORAL & WATER & ADDITION \\
\cline { 2 - 6 } & $K g$ & $K g$ & $K g$ & $L$ & $K g$ \\
\hline BT-N & 2.03 & 3.67 & 5.51 & 1.37 & - \\
\hline BT-N-L Asbes $50 \%$ & 1.15 & 3.67 & 5.51 & 1.37 & 1.15 \\
\hline BT-L Asbes $100 \%$ & - & 3.67 & 5.51 & 1.37 & 2.03 \\
\hline
\end{tabular}

Source : plan Jobmix Concrete Modified Per Cylinder

Table 4. shows that with the percentage addition of $50 \%$ asbestos waste, there was a reduction in the amount of cement by 1.15 . In comparison, with the percentage of adding asbestos waste, $100 \%$ replaced cement with asbestos waste.

\section{Slump Test Results}

The results of the slump test for each variation in the addition of asbestos waste can be seen in Figure 4.

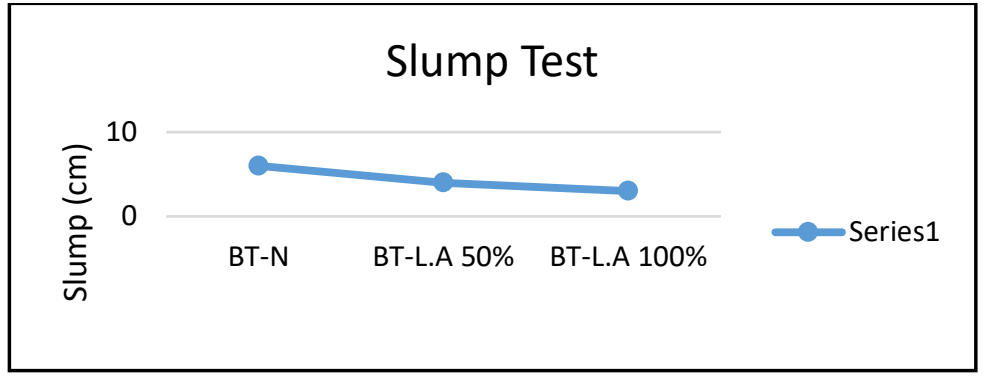

Figure 4. Slump Test Results

\section{Compressive Strength Test Results}

The results of the concrete compressive strength test after the concrete is 28 days old for each variation of the concrete mix, and each specimen are shown in Table 5.

Table 5. Results of Concrete Compressive Strength Value

\begin{tabular}{|c|c|c|c|}
\hline Sample & BT-N & BT-L.A 50\% & BT-L.A 100\% \\
\hline 1 & 19,36 & 19,36 & 19,83 \\
\hline 2 & 20,77 & 20,77 & 21,24 \\
\hline 3 & 22,65 & 21,24 & 21,71 \\
\hline 4 & 23,59 & 22,65 & 23,12 \\
\hline 5 & 24,04 & 22,59 & 28,76 \\
\hline Average & 22,08 & 21,32 & 22,93 \\
\hline
\end{tabular}

Source : of concrete compressive strength test results

From the table above, the average compressive strength of standard concrete is Fc $22.08 \mathrm{Mpa}$, mixed concrete with a percentage of $50 \%$ asbestos waste with a result of Fc $21.32 \mathrm{Mpa}$, and concrete with a mixture of $100 \%$ asbestos waste with a consequence of Fc $22.93 \mathrm{Mpa}$. 


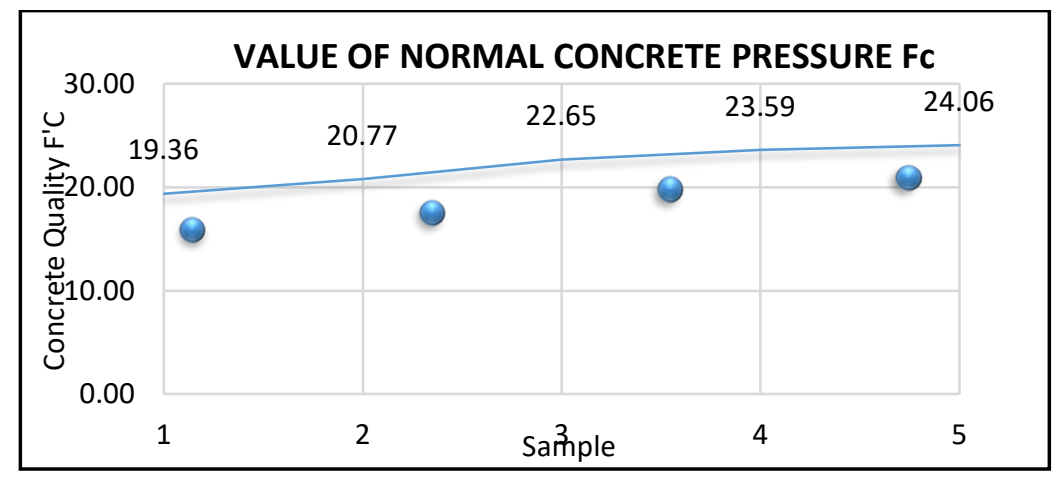

Figure 5. Standard Concrete Compressive Strength Value

Figure 5 shows that the average compressive strength of standard concrete is Fc '22.08 MPa

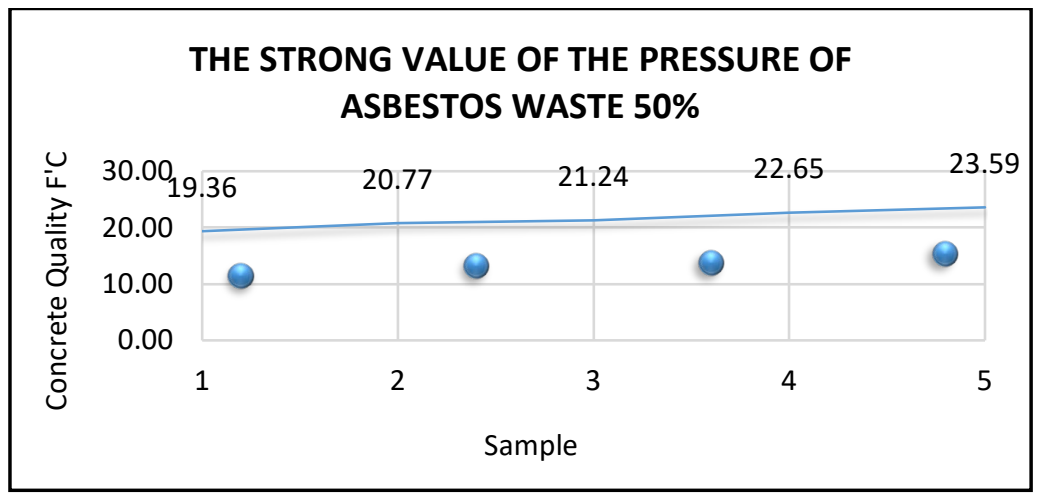

Figure 6. Value of Concrete Compressive Strength Asbestos Waste $50 \%$

Figure 6 shows that the compressive strength of asbestos waste with a percentage of $50 \%$ is smaller than the rate of $100 \%$ with the highest compressive strength value of $28.76 \mathrm{Mpa}$

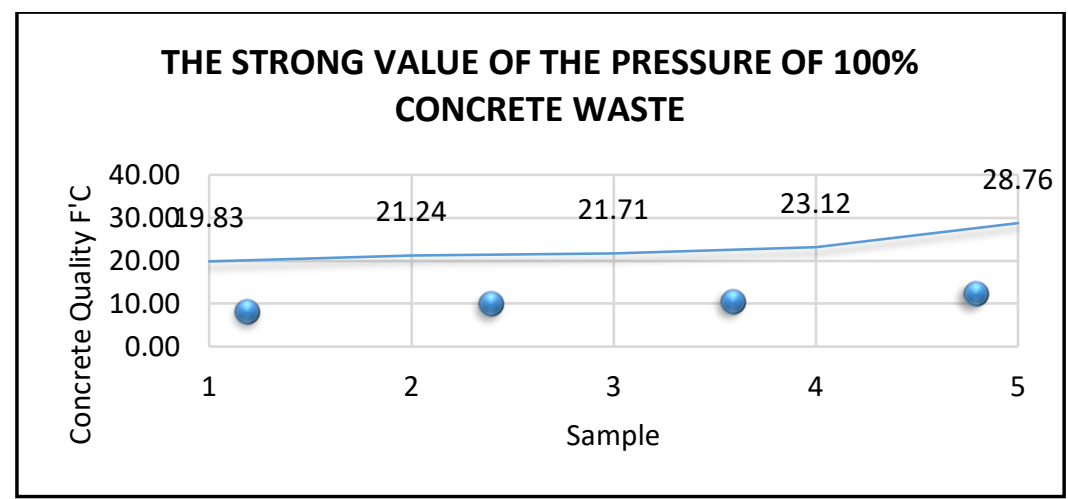

Figure 7. Value of Concrete Compressive Strength Asbestos Waste 100\%

Figure 7 shows that the highest compressive strength is achieved by asbestos waste concrete with a percentage of $100 \%$ 


\section{CONCLUSIONS}

After the whole material testing process has been carried out; from this research, several conclusions can be drawn as follows.

1. That the slump value obtained for standard concrete is $6 \mathrm{~cm}$ in value, for mixed concrete with $50 \%$ asbestos waste with an amount of $4 \mathrm{~cm}$, and for mixtures of $100 \%$ asbestos waste with a value of $3 \mathrm{~cm}$.

2. The test results of the compressive strength of concrete with standard combinations and variations in the addition of asbestos waste at the age of 28 days have different average results of compressive force. The average compressive strength value of standard concrete is $22.04 \mathrm{Mpa}$, while the average compressive strength value using variations in the addition of $50 \%$ asbestos waste is $21.32 \mathrm{MPa}$, and the average compressive strength value of concrete with a percentage of asbestos waste is $100 \%$ amounted to 22.93

\section{REFERENCES}

Badan Standardisasi Nasional. (2002). Tata Cara Perhitungan Struktur Beton Untuk Bangunan Gedung. SNI 032847-2002. Bandung: Badan Standardisasi Nasional, umum, 251.

Breu, F., Guggenbichler, S., \& Wollmann, J. (2008). Ultra-High Strength Concrete Mixtures Using Local Materials. Vasa, 575, 1-13. https://doi.org/10.1017/CBO9781107415324.004

Cahyo, Y. (2020). The Effect of Stirring Time and Concrete Compaction on K-200 Concrete Press Strength. https://doi.org/10.1088/1742-6596/1569/4/042033

Candra, A. I. (2020). Correlation of Concrete Strength and Concrete Age K-300 Using Sikacim ${ }^{\circledR}$ Concrete Additive and Master Ease 5010 Correlation of Concrete Strength and Concrete Age K-300 Using Sikacim ® Concrete Additive and Master Ease 5010. https://doi.org/10.1088/1742-6596/1569/4/042032

Chai Lee, J., Shafigh, P., \& Kim Lee, S. (2019). High Strength Concrete Incorporating Oil-Palm-Boiler Clinker as Coarse Lightweight Aggregate. IOP Conference Series: Materials Science and Engineering, 601(1). https://doi.org/10.1088/1757-899X/601/1/012017

Chan, Y. W., \& Chu, S. H. (2004). Effect of silica fume on steel fiber bond characteristics in reactive powder concrete. Cement and Concrete Research, 34(7), 1167-1172. https://doi.org/10.1016/j.cemconres.2003.12.023

Dachlan, A. T., \& Setiadji, R. (2015). ( Usage of Merapi Sand for High-Grade Concrete ). 16-31.

Gowdham, K., Sumathi, A., \& Saravana Raja Mohan, K. (2017). Study on the strength characteristics of High strength concrete with Micro steel fibers. IOP Conference Series: Earth and Environmental Science, 80(1). https://doi.org/10.1088/1755-1315/80/1/012010

Kasim, N., Sulaiman, M. R., \& Taib, K. A. (2019). Utilization of ultra - High performance concrete for bridge construction - A case study of $\mathrm{Kg}$. Seberang Manong to Pekan Manong bridge. IOP Conference Series: Materials Science and Engineering, 512(1). https://doi.org/10.1088/1757-899X/512/1/012036

Kusumawardaningsih, Y., Fehling, E., Ismail, M., \& Aboubakr, A. A. M. (2015). Tensile strength behavior of UHPC and UHPFRC. Procedia Engineering, 125, 1081-1086. https://doi.org/10.1016/j.proeng.2015.11.166

Larsen, I. L., Granseth Aasbakken, I., O'Born, R., Vertes, K., \& Thorstensen, R. T. (2017). Determining the Environmental Benefits of Ultra High Performance Concrete as a Bridge Construction Material. IOP Conference Series: Materials Science and Engineering, 245(5). https://doi.org/10.1088/1757899X/245/5/052096

Maghfouri, M., Shafigh, P., Binti Ibrahim, Z., \& Alimohammadi, V. (2017). Quality control of lightweight aggregate concrete based on initial and final water absorption tests. IOP Conference Series: Materials Science and 
Engineering, 210(1). https://doi.org/10.1088/1757-899X/210/1/012022

Malier. (1992). Pembuatan Ultra High Strength Concrete Dengan Material Lokal. 1-8.

Pujianto, A. (2011). Beton Mutu Tinggi dengan Admixture Superplastisizer dan Aditif Silicafume. Jurnal IImiah Semesta Teknika, 14(2), 177-185.

Qasim, O. A. (2018). Experimental investigation on autogenous shrinkage of high and ultra-high strength concrete. IOP Conference Series: Materials Science and Engineering, 454(1). https://doi.org/10.1088/1757$899 X / 454 / 1 / 012067$

Ratnawulan, R., Fauzi, A., \& Hayati, A. E. S. (2018). Characterization of Silica Sand Due to the Influence of Calcination Temperature. IOP Conference Series: Materials Science and Engineering, 335(1). https://doi.org/10.1088/1757-899X/335/1/012008

Ridwan, A., Candra, A. I., \& Gardjito, E. (n.d.). Experimental Study Additional Brantas Sands Of Clay Density. 611.

S Winarto. (2020). ANALYSIS CAUSES CONCRETE DAMAGE AND PREVENTION. https://doi.org/10.1088/1742-6596/1569/4/042031

Sathyan, D., Anand, K. B., Mini, K. M., \& Aparna, S. (2018). Optimization of superplasticizer in portland pozzolana cement mortar and concrete. IOP Conference Series: Materials Science and Engineering, 310(1). https://doi.org/10.1088/1757-899X/310/1/012036

Zhang, X., \& Zhang, H. (2019). Experimental Research on Ultra-High Performance Concrete (UHPC). IOP Conference Series: Materials Science and Engineering, 562(1). https://doi.org/10.1088/1757$899 X / 562 / 1 / 012045$

(C) 2020 by the authors. Submitted for possible open access publication under the terms and conditions of the Creative Commons Attribution (CC BY SA) license (https://creativecommons.org/licenses/by-sa/3.0/). 